\title{
Dentatin from Clausena excavata Induces Apoptosis in HepG2 Cells via Mitochondrial Mediated Signaling
}

\author{
A Reenaa Joys Andas ${ }^{1,2 *}$,Ahmad Bustamam Abdul ${ }^{1}$, Heshu Sulaiman Rahman ${ }^{1}$, \\ Mohd Aspollah Sukari ${ }^{3}$, Siddig Ibrahim Abdelwahab ${ }^{4}$, Nozlena Abdul Samad ${ }^{1}$, \\ Theebaa Anasamy ${ }^{1}$, Ismail Adam Arbab ${ }^{1}$
}

\begin{abstract}
Hepatocellular carcinoma (HCC) is a primary liver cancer with high global incidence and mortality rates. Current candidate drugs to treat $\mathrm{HCC}$ remain lacking and those in use possess undesirable side effects. In this investigation, the antiproliferative effects of dentatin (DTN), a natural coumarin, were evaluated on HepG2 cells and DTN's probable preliminary molecular mechanisms in apoptosis induction were further investigated. DTN significantly $(\mathrm{p}<0.05)$ suppressed proliferation of HepG2 cells with an $\mathrm{IC}_{50}$ value of $12.0 \mu \mathrm{g} / \mathrm{mL}$, without affecting human normal liver cells, WRL-68 $\left(\mathrm{IC}_{50}>50 \mu \mathrm{g} / \mathrm{mL}\right)$ causing $\mathrm{G}_{0} / \mathrm{G}_{1}$ cell cycle arrest via apoptosis induction. Caspase colorimetric assays showed markedly increased levels of caspase-3 and caspase-9 activities throughout the treatment period. Western blotting of treated HepG2 cells revealed inhibition of NF- $x$ B that triggers the mitochondrial-mediated apoptotic signaling pathway by up-regulating cytoplasmic cytochrome $\mathrm{c}$ and Bax, and down-regulating Bcl-2 and Bcl-xL. The current findings suggest DTN has the potential to be developed further as an anticancer compound targeting human HCC.
\end{abstract}

Keywords: Dentatin - HepG2 - apoptosis - mitochondrial-mediated signaling pathway

Asian Pac J Cancer Prev, 16 (10), 4311-4316

\section{Introduction}

Hepatocellular carcinoma (HCC), known as malignant hepatoma is a primary cancer of the liver. $\mathrm{HCC}$ is the third most common cause of cancer-related deaths globally after lung and stomach cancer. As per GLOBOCAN report, in 2008, 749,000 recent cases of HCC were identified globally and its related deaths were recognized to be 695,000 accounting for the high incidence to mortality ratio (Ferlay et al., 2013). Initially, the focus of HCC treatment was on systemic, nonspecific, high-dose chemotherapy, but currently there is a need to invent a drug that balances minimal adverse effects with maximal antitumor activity (Abou-Jawde et al., 2003).

Breakthroughs in plant-derived anticancer agents had begun to show significant growth in drug discovery (Sultana et al., 2014). Analyses that include cytotoxicity testing provide crucial means of ranking compounds for consideration in anticancer drug discovery whereas, multiparametric in vitro analysis, which evaluates apoptosis induction is able to provide important data regarding undesirable side-effects and further to conclude that the compound under investigation is tumor specific, non-redundant, and able to hinder tumor progression (Niles et al., 2008; Zhang et al., 2014).
Clausena excavata Burm.f., a wild shrub, is extensively distributed throughout Southeast Asia belonging to the family of Rutaceae and has been used as folk medicine for the treatment of several disorders and diseases (Mohan, 2012). Their therapeutic properties have been mainly attributed to the presence of carbazole alkaloids and coumarins (Wu and Furukawa, 1982; Wu et al., 1996; Sunthitikawinsakul et al., 2003; Taufiq-Yap et al., 2007; Kumar et al., 2012).

DTN is known for its cytotoxicity against various cancer cells as previously reported, which included human prostate cancer cells (LNCaP and PC-3) (Arbab et al., 2012) and human breast cancer cells (MCF-7) (Arbab et al., 2013). In this current investigation, the antiproliferative effects of DTN were evaluated on HCC cells, HepG2 and the probable molecular mechanism of DTN that causes cell death in HepG2 cells via apoptosis induction was further investigated.

\section{Materials and Methods}

\section{Compound isolation and purification}

C. excavata was sourced from Pendang, Kedah in December 2010 and identified at the Herbarium Unit, Institute of Bioscience, University Putra Malaysia (UPM).

${ }^{1}$ UPM-MAKNA Cancer Research Laboratory, Institute of Bioscience, ${ }^{2}$ Biostatistics Unit, National Clinical Research Centre, Kuala Lumpur, ${ }^{3}$ Department of Chemistry, Faculty of Science, Universiti Putra Malaysia, Serdang, Malaysia, ${ }^{4}$ Medical Research Center, Faculty of Medicine, Jazan University, Saudi Arabia*For correspondence: reenaa.joys@gmail.com 
The roots $(1.5 \mathrm{~kg})$ of $C$. excavata were air-dried and ground before extraction. DTN was isolated and purified by one of the co-author. The compound was sent for infrared (IR) and nuclear magnetic resonance (NMR) analyses at the Laboratory of Spectroscopic Analysis, Faculty of Science, UPM. The purity $(>96.42 \%)$ was determined by means of HPLC and LC-MS. Recently, DTN has been isolated and characterized using IR and NMR (Arbab et al., 2012; Sharif et al., 2013). The spectral data were found to be similar as previously reported by Xin and the team (Xin et al., 2008).

\section{Reagents}

DTN was dissolved in DMSO and added to the cell culture with a final DMSO concentration of $0.1 \% \mathrm{w} / \mathrm{v}$. Only analytical grade reagents were used.

\section{Cell culture and maintenance}

HepG2 cells and WRL-68 cells were sourced from American Type Culture Collection (ATCC). Culturing of both cells in RPMI 1640 (Nacalai Tesque, Japan) was done, supplemented with $10 \%$ Fetal Bovine Serum (Life Technologies, USA) and 1\% Antibiotic-Antimycotic (Nacalai Tesque, Japan), maintained at $37^{\circ} \mathrm{C} / 5 \% \mathrm{CO}_{2}$.

\section{Cell proliferative assay}

Cell proliferation assay was quantified by the ability of living cells to reduce the yellow MTT dye by mitochondrial succinate dehydrogenase, resulting in the production of formazan purple crystals as described by Mosmann, 1983. Briefly, cell suspension of HepG2 (100 $\mu \mathrm{L} /$ well) was seeded at densities of $2 \times 10^{5}$ cells $/ \mathrm{mL}$ into 96 well microtiter plates and treated with DTN of different concentrations $(100 \mu \mathrm{g} / \mathrm{mL}, 50 \mu \mathrm{g} / \mathrm{mL}, 25 \mu \mathrm{g} / \mathrm{mL}, 12.5$ $\mu \mathrm{g} / \mathrm{mL}, 6.25 \mu \mathrm{g} / \mathrm{mL}$ and $3.125 \mu \mathrm{g} / \mathrm{mL}$ ) and followed by incubation in atmosphere of $5 \% \mathrm{CO}_{2}$ at $37^{\circ} \mathrm{C}$ for 68 h. MTT stock solution $(5 \mathrm{mg} / \mathrm{mL})$ at a volume of $10 \%$ $(20 \mu \mathrm{L})$ of the medium volume was added per well and further incubated at $37^{\circ} \mathrm{C}$ for $4 \mathrm{~h}$, away from light. This was followed by the removal of media and the formazan crystals that resulted were solubilized by adding 100 $\mu \mathrm{L}$ of DMSO with gentle swirling. The absorbance was measured at $595 \mathrm{~nm}$ with a microliter plate reader (Tecan Sunrise basic, Groedig, Austria). The viability of the cell was expressed as a percentage of absorbance relative to vehicle-treated cell control. DTN was also tested for its cytotoxicity on WRL-68 cells and paclitaxel was used as positive control.

\section{Morphological assessment via phase contrast inverted microscope}

HepG 2 cells at $2 \times 10^{5}$ cells/mL density then underwent treatment with DTN $\left(\mathrm{IC}_{50}\right)$ for $24 \mathrm{~h}, 48 \mathrm{~h}$ and $72 \mathrm{~h}$. The changes in the morphology of treated cells were compared to untreated control cells observed under Phase Contrast Inverted Microscope equipped with NIS-Elements D software (Nikon).

Confocal microscopic Assessment using AO/PI Double Staining

Briefly, HepG2 cells were seeded at a density of $2 \times 10^{5}$ cells $/ \mathrm{mL}$ and treated with DTN $\left(\mathrm{IC}_{50}\right)$ for $24 \mathrm{~h}, 48 \mathrm{~h}$ and 72 h. Cells not treated served as negative control. This was followed by the addition of $10 \mu \mathrm{L}(10 \mu \mathrm{L})$ of fluorescent dyes, (AO/PI) with acridine orange (AO), $(10 \mu \mathrm{g} / \mathrm{mL})$ and propidium iodide $(\mathrm{PI}),(10 \mu \mathrm{g} / \mathrm{mL})$ into the harvested cell pellet in equal volumes of each. Appropriate volume of freshly stained cell suspension was dropped onto a glass slide and covered by coverslip. The coverslip was then sealed with nail polish. Concurrently, the coverslip was observed under the Confocal Laser Scanning Microscope equipped with Qfluoro software (Zeiss, Germany) within 30 minutes before the fluorescent color started to fade.

\section{Annexin V-FITC/PI assay}

Loss of membrane asymmetry was detected using Annexin V-FITC Kit according to manufacturer's protocol (MACS Miltenyi Biotech, USA). HepG2 cells at a density of $1 \times 10^{6}$ cells $/ \mathrm{mL}$ were treated with DTN $\left(\mathrm{IC}_{50}\right)$ in time-dependent manner (6h, 12h, 24h, 48h, and 72h). Untreated cells served as the negative control. Harvested cells were washed, resuspended in $1 \mathrm{X}$ binding buffer and incubated with Annexin-V FITC and PI prior to the analysis on Fluorescence-activated cell sorting (FACS) by flow cytometer (BD Bioscience, California) equipped with CellQuest Pro software.

\section{Analysis of cellular DNA content}

Briefly, HepG2 cells of $2 \times 10^{6}$ cells $/ \mathrm{mL}$ density were treated with DTN $\left(\mathrm{IC}_{50}\right)$ for $24 \mathrm{~h}, 48 \mathrm{~h}$ and $72 \mathrm{~h}$ with negative control served by untreated cells. Harvested cells were fixed with $70 \%$ cold ethanol and stored frozen $\left(-20^{\circ} \mathrm{C}\right)$ up to 1 week. Cells were then incubated in staining solution $(0.2 \mathrm{mg} / \mathrm{ml} \mathrm{RNAse}$ A and $50 \mu \mathrm{g} / \mathrm{mL}$ PI $)$. Samples were kept in the dark at room temperature for 30 minutes, prior to the analysis on FACS by flow cytometer, equipped with CellQuest Pro software.

\section{Caspase-3/8/9 activity}

Caspase activity was determined using Caspase-3/8/9 Colorimetric Assay Kit as per manufacturer's protocol (GenScript, USA). Seeding of HepG2 cells was done at a density of $4 \times 10^{6}$ cells $/ \mathrm{mL}$ and followed by treatment with DTN $\left(\mathrm{IC}_{50} \mathrm{c}\right.$ for $12 \mathrm{~h}, 24 \mathrm{~h}, 48 \mathrm{~h}$ and $72 \mathrm{~h}$. At the same time, negative control was set. Resuspension of the cells was done in cold lysis buffer followed by incubation on ice for $1 \mathrm{~h}$. After centrifugation, $10 \mu \mathrm{L}$ of supernatant was used to assay the protein concentration by Bradford method. Equal amounts of protein were mixed with $2 \mathrm{X}$ reaction buffer and $200 \mu \mathrm{M}$ DEVD-pNA substrate (caspase-3)/ IETD-pNA substrate (caspase-8)/ LEHD-pNA substrate (caspase-9) and further incubated at $37^{\circ} \mathrm{C}$ for $4 \mathrm{~h}$, away from light. The plates were read at $405 \mathrm{~nm}$.

\section{Western blotting}

HepG2 cells underwent treatment with DTN $\left(\mathrm{IC}_{50}\right)$ for $12 \mathrm{~h}, 24 \mathrm{~h}$ and $48 \mathrm{~h}$. Untreated cells served as the negative control. Protein extraction was done using Cytobuster ${ }^{\mathrm{TM}}$ Protein Extraction Reagent following manufacturer's protocol (Novagen, USA) and the protein concentrations were quantified by Bradford method. Protein samples (20 
Dentatin from Clausena excavata Induces Apoptosis in HepG2 via Mitochondrial Mediated Signaling

Table 1. Flow Cytometric Analysis of Annexin V-FITC/PI of HepG2 Cells Treated with DTN $\left(\right.$ IC $_{50}$ ) in a Time Dependent Manner

\begin{tabular}{|c|c|c|c|c|c|c|}
\hline & Control & $6 \mathrm{H}$ & $12 \mathrm{H}$ & $24 \mathrm{H}$ & $48 \mathrm{H}$ & $72 \mathrm{H}$ \\
\hline VIABLE & $97.19 \pm 0.65$ & $95.42 \pm 0.81 *$ & $93.80 \pm 0.5^{*}$ & $84.35 \pm 0.15^{*}$ & $70.70 \pm 0.20 *$ & $42.01 \pm 0.21 *$ \\
\hline EARLY APOPTOSIS & $2.27 \pm 0.11$ & $3.39 \pm 0.26 *$ & $3.87 \pm 0.17 *$ & $10.74 \pm 0.14 *$ & $16.82 \pm 0.44^{*}$ & $20.62 \pm 0.13 *$ \\
\hline LATE APOPTOSIS & $0.42 \pm 0.11$ & $0.76 \pm 0.17$ & $1.80 \pm 0.19 *$ & $3.42 \pm 0.30 *$ & $9.42 \pm 0.10 *$ & $24.52 \pm 0.44 *$ \\
\hline SECONDARYNECROSIS & $0.12 \pm 0.07$ & $0.43 \pm 0.12$ & $0.52 \pm 0.20$ & $1.49 \pm 0.20 *$ & $3.06 \pm 0.19 *$ & $12.85 \pm 0.41 *$ \\
\hline
\end{tabular}

$\mu \mathrm{g})$ were separated by SDS-PAGE and transferred to a PVDF membrane using a wet transfer system (Bio-Rad, USA). After blocking with 5\% non-fat dry milk and $0.05 \%$ Tween-20 in Tris-buffered saline (TBS), the membranes were incubated overnight with the primary antibody [Betaactin (1:10000), Bcl-2 (1:2000), Bax (1:2000), Bcl-xL (1:1000), Cytochrome c (1:1000) and NF- $x \mathrm{~B}(1: 1000)]$ followed by incubation with Goat Anti-Mouse $\mathrm{IgG}(\mathrm{H}+\mathrm{L})$ Alkaline Phosphatase (AP) Conjugate (Bio-Rad, USA). AP Conjugate Substrate Kit (Bio-Rad, USA) was used for the color development and photographs were taken while the membrane was wet to enhance the purple color. ImageJ software was then used to quantify the intensity of the .bands

\section{Statistical analysis}

Each experiment was performed in triplicate. Data were presented as mean $\pm \mathrm{SD}$ and analyzed by One Way ANOVA and Tukey's Test using IBM SPSS Statistics 20. Differences with $\mathrm{p}<0.05$ were considered statistically significant.

\section{Results and Discussion}

DTN exhibits potent antiproliferative effect on HepG2 and not on WRL-68

DTN was screened for cytotoxicity on several cancer cells, namely HepG2, CEMss, HeLa and HT29, using the MTT colorimetric assay. Results of the assay (data not shown) showed that, DTN exerted highest cytotoxicity effect on HepG2 cells with $\mathrm{IC}_{50}$ value of $12.03 \mu \mathrm{g} / \mathrm{mL}$. Treatment of normal human liver cells, WRL-68 cells with DTN showed no evidence of significant inhibition up to $50 \mu \mathrm{g} / \mathrm{mL}$ after $72 \mathrm{~h}$ of incubation. Paclitaxel, used as positive control, exhibited an inhibitory effect on HepG2 cells at $\mathrm{IC}_{50}$ value of $2.32 \pm 0.05 \mu \mathrm{g} / \mathrm{mL}$ after $72 \mathrm{~h}$ treatment.

\section{DTN shows distinct cell death related morphological} features

Microscopy assessment of cellular morphological changes attributed to DTN treatment in HepG2 cells was made. In respect to this, morphological changes in response to DTN's $\left(\mathrm{IC}_{50}\right)$ treatment in HepG2 cells at exposure time of $24 \mathrm{~h}, 48 \mathrm{~h}$ and $72 \mathrm{~h}$ were compared to untreated HepG2 cells using phase contrast inverted microscope. Figure 1 shows features of cell shrinkage and membrane blebbing following DTN's treatment in a time-dependent manner. In addition to using this evaluation, other microscopic assessment using dyes to detect cellular morphological changes possibly relating to apoptosis induction were later used to provide evidence of
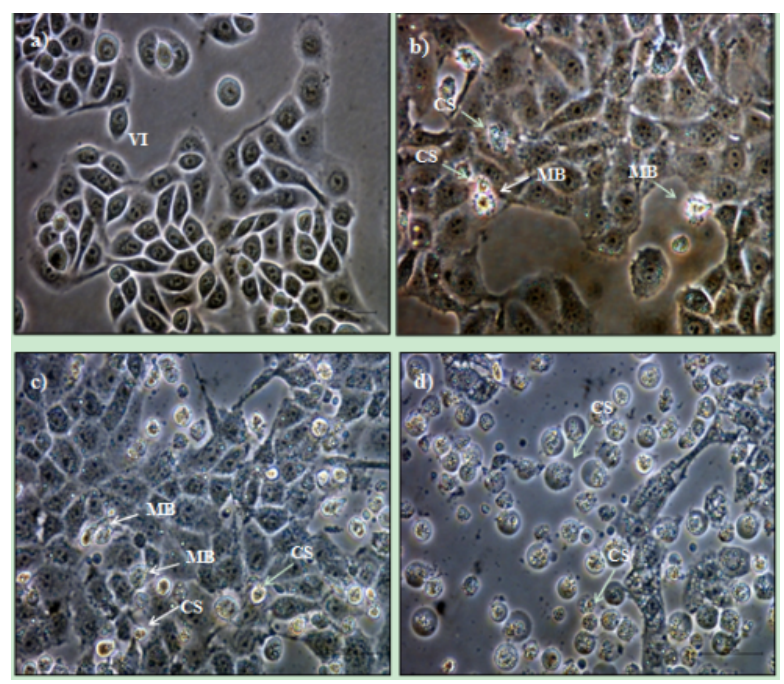

Figure 1. Phase-Contrast Inverted Micrographs of HepG2 Cells Treated with DTN $\left(\mathrm{IC}_{50}\right)$. a) Control, show an epithelial-like morphology, presented normal, healthy form demonstrated by clear skeletons b) $24 \mathrm{~h}$, cells lose contact with adjacent cells, as rapid cell shrinkage occurs concurrently to nuclear changes, forming a blebbing surface on the cell c) $48 \mathrm{~h}$, rapid growth inhibition leading to detachment of the cell and membrane blebbing and d) $72 \mathrm{~h}$, detachment of most of the cells with apparent cell shrinkage. VI: Viable Cell, MB: Membrane Blebbing, CS: Cell Shrinkage
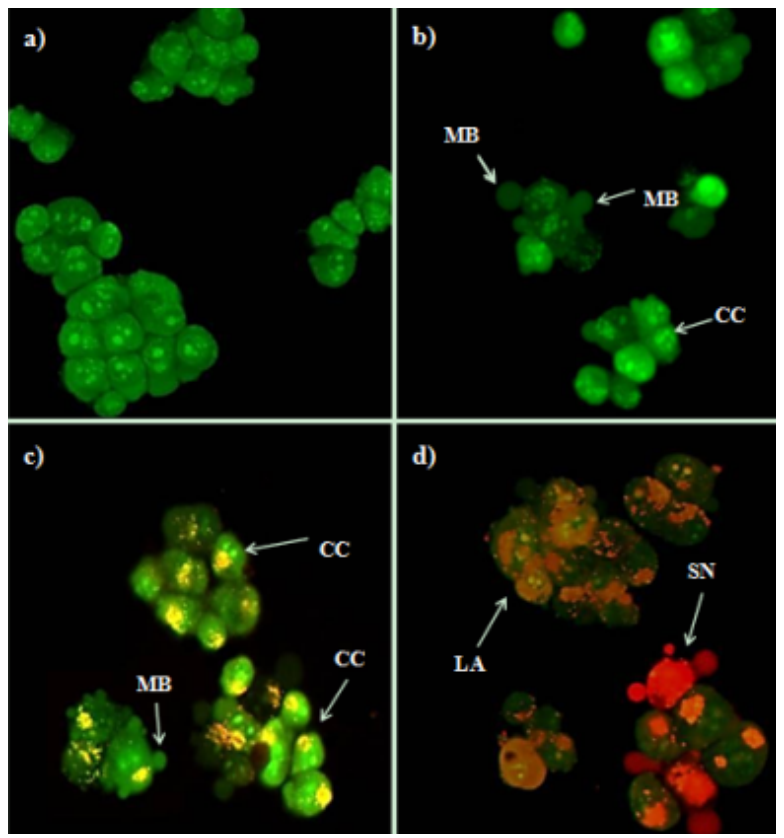

Figure 2. AO/PI Stained Confocal Micrographs of DTN ( $\left(\mathrm{IC}_{\mathbf{5 0}}\right.$ ) Treated HepG2 Cells.a) Control b) $\left.24 \mathrm{~h}, \mathrm{c}\right) 48$ $\mathrm{h}$ and d) $72 \mathrm{~h}$. VI: Viable Cell, MB: Membrane Blebbing, CC: Chromatin Condensation, LA: Late Apoptosis, SN: Secondary Necrosis 
A Reenaa Joys Andas et al
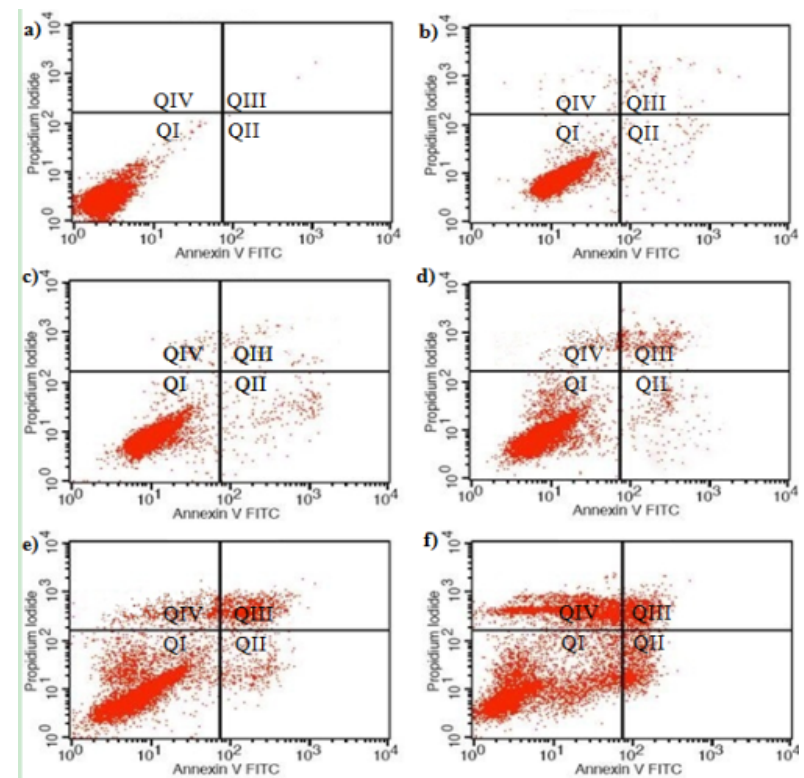

Figure 3. Scatter Profile of Flow Cytometric Analysis of Annexin V-FITC/PI of DTN ( IC $\left._{50}\right)$ Treated HepG2 Cells in Time Dependent Manner. a) Control,b) 6h,c) 12h, d) $24 \mathrm{~h}$, e) $48 \mathrm{~h}$ and f) $72 \mathrm{~h}$. QI: viable cells, QII: early apoptotic cells, QIII: late apoptotic cells, QIV: secondary necrotic cells
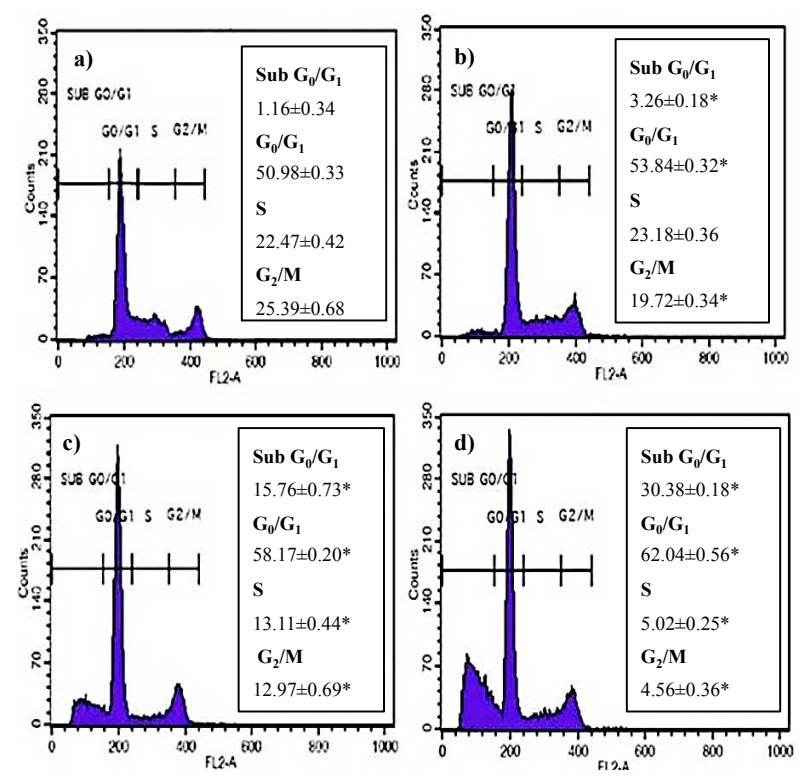

Figure 4. Flow Cytometric Analysis of Cellular DNA Content Frequency Histograms of HepG2 Cells Treated with DTN $\left(\mathrm{IC}_{50}\right)$ in Time Dependent Manner. a) Control, b) $24 \mathrm{~h}$, c) $48 \mathrm{~h}$ and d) $72 \mathrm{~h}$. Sub $\mathrm{G}_{0} / \mathrm{G}_{1}$ denotes apoptotic DNA with hypodiploid DNA content

this phenomenon. Viable, early apoptosis, late apoptosis and secondary necrosis states of cells were determined using acridine orange (AO) and propidium iodide (PI) fluorescent dyes (Foglieni et al., 2001). Following this, confocal microscopic examination of DTN $\left(\mathrm{IC}_{50}\right)$ treated HepG2 cells in a time-dependent manner after AO/PI staining revealed typical cellular morphological changes of HepG2 cells associated with cell death via probable apoptosis induction (Figure 2). Untreated control showed healthy HepG2 cells possessing weak green nuclei of proliferated uncontrolled growth (Figure 2-a). After 24

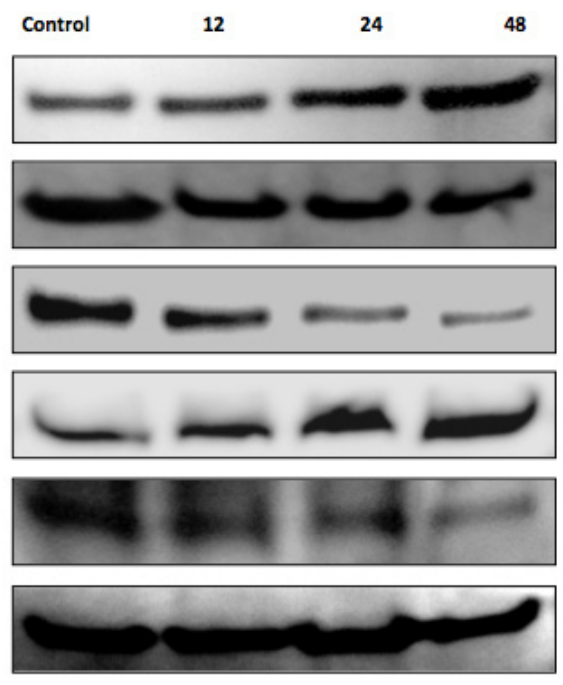

Figure 5. Western Blotting Analysis Showing Regulation of Bax, Bcl-2, Bcl-xL, Cytochrome c, NF$\chi \mathrm{B}$ and $\beta$-actin (Loading Control) protein expression in DTN $\left(\mathrm{IC}_{50}\right)$ Treated HepG2 Cells after $12 \mathrm{~h}, 24 \mathrm{~h}$ and 48h with Untreated Control

h treatment, HepG2 cells were bright green with yellow nuclei, denoting evidence of condensed chromatin (Figure 2-b). Early apoptosis and late apoptosis features were observed after respective $48 \mathrm{~h}$ (Figure 2-c) and $72 \mathrm{~h}$ treatments (Figure 2-d), which include bright green cells of yellow nucleic, membrane blebbing and orange intact cells. Apoptotic cells going through secondary necrosis were found following $72 \mathrm{~h}$ treatment where cells displayed reddish orange intact nucleus (Figure 2-d).

\section{DTN induces loss of membrane asymmetry}

The key features of loss of membrane asymmetry are the exposure of phosphotidylserine (PS) from the inner face of plasma membrane to the surface of the cell (Van Engeland et al., 1996; Van Engeland et al., 1998). Thus, in order to discriminate the integrity of cell membrane, FITC labelled Annexin V together with a dye exclusion of PI were performed to target and detect early apoptotic cells before a cell loses its membrane integrity (Vermes et al., 1995; Van Engeland et al., 1996). Apoptotic cells were counted as early or late apoptotic cells, which are shown repeatedly in the lower right (Annexin V/FITC+PI-) and upper right (Annexin V/FITC+PI+) quadrants of the scatter profile of DTN $\left(\mathrm{IC}_{50}\right)$ treated HepG2 cells in increasing treatment time (Figure 3 ). There was a significant increase $(\mathrm{p}<0.05)$ of the apoptotic cells from an untreated control $(2.69 \%)$, such increase occurring in a time-dependent manner at $4.15 \%, 5.67 \%, 14.16 \%, 26.24 \%$ and $45.14 \%$ after $6 \mathrm{~h}, 12 \mathrm{~h}, 24 \mathrm{~h}, 48 \mathrm{~h}$ and $72 \mathrm{~h}$ treatments respectively.

\section{DTN induces $G_{0} / G_{1}$ cell cycle arrest}

DTN induced a concomitant accumulation of cells in the $\mathrm{G}_{0} / \mathrm{G}_{1}$ phase, with an apparent increase $(\mathrm{p}<0.05)$ from untreated HepG2 cells $(50.98 \pm 0.33 \%)$ to treated cells; $53.84 \pm 0.32 \%, 58.17 \pm 0.20 \%$ and $62.04 \pm 0.56 \%$ after $24 \mathrm{~h}$, $48 \mathrm{~h}$ and $72 \mathrm{~h}$ of treatment respectively, with subsequent decreases in $\mathrm{S}$ phase (Figure 4). These accumulations 
could be due to G1 checkpoint that made it impossible for the division of the DTN treated HepG2 cells, which then entered the $\mathrm{G} 0$ resting phase, thus signaling the $\mathrm{G}_{0} /$ $G_{1}$ phase arrest (Pucci et al., 2000). These cells were possibly eliminated through apoptosis induction (Pucci et al., 2000) as it correlated with a significant $(\mathrm{p}<0.05)$ increase of apoptotic cells (sub G0/G1), as treatment time with DTN increased in HepG2 cells.

\section{DTN induces apoptosis via mitochondrial mediated signaling pathway}

The Bcl-2 family proteins are implicated in the regulation of the mitochondrial-mediated apoptosis pathway (Shamas-Din et al., 2013; Czabotar et al., 2014; Volkmann et al., 2014). Thus, fluctuations in the proapoptotic and anti-apoptotic Bcl-2 proteins levels were investigated in DTN $\left(\mathrm{IC}_{50}\right)$ treated HepG2 cells. The Western Blotting analysis demonstrated increased proapoptotic Bax protein in a time-dependent manner (Figure 5). In contrast, anti-apoptotic proteins of Bcl-2 and Bcl-xL decreased upon DTN treatment (Figure 5).

An important stage in the mitochondrial pathway is the subsequent release of cytochrome $\mathrm{c}$ from the intermembrane space (Estaquier et al., 2012; White, 2013). Upon releasing cytochrome c into the cytosol, the permeability of mitochondria is controlled by Bcl2 proteins by either promoting or inhibiting apoptosis directly on mitochondrial permeability transition pores (Narita et al., 1998). Pro-apoptotic protein, Bax forms pores, while anti-apoptotic protein $\mathrm{Bcl}-2$ and $\mathrm{Bcl}-\mathrm{xL}$ hinder their formation (Crompton, 1999). Figure 5 shows significant $(\mathrm{p}<0.05)$ time-dependent increase of cytochrome c accumulation in the cytosol upon DTN treatment in HepG2 cells.

Transduction of apoptotic signals needs to be activated by a cascade involving caspases. Caspase-3, particularly, has a key role in executing apoptosis as it catalyzes specific cleavage of several important cellular proteins (Brentnall et al., 2013). Increase in caspase-3 activity is crucial for drug-induced apoptosis as the activation of caspase-3 is a hallmark of apoptosis and can be used in quantifying the caspase cascade (Logue and Martin, 2008). Caspase- 3 is triggered by either caspase- 8 or caspase- 9 , which acts as a convergence point for different apoptosis signaling pathways. In this current investigation, the activity of caspase- 8 remained at basal level while the activity of caspase- 9 significantly $(p<0.05)$ increased in a time dependent manner. Similarly, increase in caspase-3 activity was observed in DTN-treated HepG2 cells in a time-dependent manner and this evidently proved the use of the active form of caspase- 3 in detection events leading toward apoptotic induction. The current results correlate well with the mitochondrial signaling pathway, and as the cytochrome $\mathrm{c}$ is released, it binds to Apaf-1 protein and ATP, which in turn binds to pro-caspase-9, forming an apoptosome (Wurstle et al., 2012). The apoptosome then triggers the pro-caspase- 9 to induce the formation of active caspase-9, which simultaneously activates the caspase-3 (Logue and Martin, 2008; White, 2013).

$\mathrm{NF}-\varkappa \mathrm{B}$ is now becoming an interesting therapeutic target for the treatment of cancer. NF- $\varkappa \mathrm{B}$, an apoptosis suppressing protein, stimulates the expression of the IAPs and other proteins from the anti-apoptotic Bcl-2 family (De Almagro and Vucic, 2012; Ouyang et al., 2012). The IAPs constantly suppress apoptosis by direct inhibition of caspases-3, while anti-apoptotic members of the Bcl-2 family counteract the role of the pro-apoptotic members (De Almagro and Vucic, 2012). In this current study, the down-regulated NF- $x \mathrm{~B}$ (Figure 5) suppresses the expression of IAPs, consequently decreases cell survival and hence, triggers apoptosis. Inhibition of NF- $x \mathrm{~B}$ will increase the susceptibility to apoptosis, lead to higher cell mortality, in which NF- $x$ B regulates anti-apoptotic genes, particularly the TRAF1 and TRAF2 and, thus, activate the activities of the caspases, which are the central to most of the apoptotic processes (Dolcet et al., 2005; Kim et al., 2006).

In summary, the present study demonstrates the ability of DTN to induce apoptosis against HepG2 cells mediated by mitochondrial signaling pathway and this effect is associated with the inhibition of NF- $x \mathrm{~B}$. Further studies will focus on addressing its effects in animal models, which warrants DTN as a probable chemotherapeutic agent to treat human hepatocellular carcinoma.

\section{Acknowledgements}

The author wish to merit Fundamental Research Grant Scheme (Vot: 5524228) from University Putra Malaysia for the financial support to conduct this study. Deepest thanks to Director General of Health for permitting to publish this work.

\section{References}

Abou-Jawde R, Choueiri T, Alemany C, et al (2003). An overview of targeted treatments in cancer. Clin Therap, 25, 2121-37.

Arbab IA, Abdul AB, Sukari MA, et al (2013). Dentatin isolated from Clausena excavata induces apoptosis in MCF-7 cells through the intrinsic pathway with involvement of NF- $x \mathrm{~B}$ signalling and $\mathrm{G}_{0} / \mathrm{G}_{1}$ cell cycle arrest: A bioassay-guided approach. J Ethnopharmacol, 145, 343-54.

Arbab IA, Looi CY, Abdul AB, et al (2012). Dentatin induces apoptosis in prostate cancer cells via Bcl-2, Bcl-xL, Survivin downregulation, caspase- $9,-3 / 7$ activation, and NF- $x \mathrm{~B}$ inhibition. Evid Based Complement Alternat Med, [Epub ahed of print].

Brentnall M, Rodriguez-Menocal L, De Guevara RL, et al (2013). Caspase-9, caspase-3 and caspase-7 have distinct roles during intrinsic apoptosis. BMC Cell Biology, 14, 32 .

Crompton M (1999). The mitochondrial permeability transition pore and its role in cell death. Biochem J, 341, 233-49.

Czabotar PE, Lessene G, Strasser A, et al (2014). Control of apoptosis by the BCL-2 protein family: implications for physiology and therapy. Nature Rev Mol Cell Biol, 15, 49-63.

De Almagro M, Vucic D (2012). The inhibitor of apoptosis (IAP) proteins are critical regulators of signaling pathways and targets for anti-cancer therapy. Exp Oncol, 34, 200-11.

Dolcet X, Llobet D, Pallares J, et al (2005). NF-kB in development and progression of human cancer. Virchows Arch, 446, 475-82.

Estaquier J, Vallette F, Vayssiere J-L, et al (2012). The mitochondrial pathways of apoptosis. In 'Advances in 
A Reenaa Joys Andas et al mitochondrial medicine', Eds Springer, 157-83.

Ferlay J, Shin H, Bray F, et al (2013). GLOBOCAN 2008 v2. 0 , cancer incidence and mortality worldwide: IARC CancerBase No. 10 [Internet]. Lyon: international agency for research on cancer; 2010. This report provide estimates of the incidence of major type of cancers, at the national level, for 184 countries of the world.

Foglieni C, Meoni C, Davalli AM (2001). Fluorescent dyes for cell viability: an application on prefixed conditions. Histochem Cell Biol, 115, 223-9.

Kim H, Hawke N, Baldwin A (2006). NF- $x$ B and IKK as therapeutic targets in cancer. Cell Death Different, 13, 738-47.

Kumar R, Saha A, Saha D (2012). A new antifungal coumarin from Clausena excavata. Fitoterapia, 83, 230-3.

Logue S, Martin S (2008). Caspase activation cascades in apoptosis. Biochem Soc Transact, 36, 1-9.

Mohan DS (2012). Clausena excavata Burm. f.(Rutaceae): A review of its traditional uses, pharmacological and phytochemical properties. J Med Plants Res, [Epub ahed of print].

Narita M, Shimizu S, Ito T, et al (1998). Bax interacts with the permeability transition pore to induce permeability transition and cytochrome $\mathrm{c}$ release in isolated mitochondria. Proceed Nat Acad Sci, 95, 14681-6.

Niles AL, Moravec RA, Riss TL (2008). Update on in vitro cytotoxicity assays for drug development. Expert Opin Drug Discov, 3, 655-69.

Ouyang L, Shi Z, Zhao S, et al (2012). Programmed cell death pathways in cancer: a review of apoptosis, autophagy and programmed necrosis. Cell proliferation, 45, 487-98.

Pucci B, Kasten M, Giordano A (2000). Cell cycle and apoptosis. Neoplasia, 2, 291-9.

Shamas-Din A, Kale J, Leber B, et al (2013). Mechanisms of action of Bcl-2 family proteins. Cold Spring Harb Perspect Biol, 5, 008714.

Sharif NM, Mustahil N, Noor NM, et al (2013). Cytotoxic constituents of Clausena excavata. African J Biotech, 10, 16337-41.

Sultana S, Asif HM, Nazar H, et al (2014). Medicinal plants combating against cancer-a green anticancer approach. Asian Pac J Cancer Prev, 15, 4385-94.

Sunthitikawinsakul A, Kongkathip N, Kongkathip B, et al (2003). Coumarins and carbazoles from Clausena excavata exhibited antimycobacterial and antifungal activities. Planta Medica, 69, 155-7.

Taufiq-Yap Y, Peh T, Ee G, et al (2007). A new cytotoxic carbazole alkaloid from Clausena excavata. Natural Product Res, 21, 810-3.

Van Engeland M, Nieland LJ, Ramaekers FC, et al (1998). Annexin $\mathrm{V}$-affinity assay: a review on an apoptosis detection system based on phosphatidylserine exposure. Cytometry, 31, 1-9.

Van Engeland M, Ramaekers FC, Schutte B, et al (1996). A novel assay to measure loss of plasma membrane asymmetry during apoptosis of adherent cells in culture. Cytometry, 24, 131-9.

Vermes I, Haanen C, Steffens-Nakken H, et al (1995). A novel assay for apoptosis flow cytometric detection of phosphatidylserine expression on early apoptotic cells using fluorescein labelled annexin V. J Immunol Methods, 184, 39-51.

Volkmann N, Marassi F, Newmeyer D, et al (2014). The rheostat in the membrane: BCL-2 family proteins and apoptosis. Cell Death Different, 21, 206-15.

White J (2013). Apoptosis: the intrinsic pathway. Mol Oncol, 367.
Wu T-S, Furukawa H (1982). Biological and phytochemical investigation of Clausena excavata. J Natural Products, 45, 718-20.

Wu T-S, Huang S-C, Wu P-L, et al (1996). Carbazole alkaloids from Clausena excavata and their biological activity. Phytochemistry, 43, 133-40.

Würstle ML, Laussmann MA, Rehm M (2012). The central role of initiator caspase- 9 in apoptosis signal transduction and the regulation of its activation and activity on the apoptosome. Experimental Cell Res, 318, 1213-20.

Xin Z-Q, Lu J-J, Ke C-Q, et al (2008). Constituents from Clausena excavata. Chem Pharmaceut Bull, 56, 827-30.

Zhang S-F, Wang X-L, Yang X-Q, et al (2014). Autophagy associated targeting pathways of natural products during cancer treatment. Asian Pac J Cancer Prev, 15, 10557-63. 